\title{
PENGUJIAN EKSTRAK KELUWAK TERHADAP AKTIVITAS REPRODUKSI DENGAN MODEL Drosophila melanogaster
}

\author{
Nurul Hidayah Base, Mufidah Murdifin, Firzan Nainu \\ Fakultas Farmasi, Universitas Hasanuddin, Makassar
}

Kata Kunci :

Keluwak, Antioksidan Lalat buah, Aktivitas Reproduksi

\section{Masuk 01-02-2017 \\ Revisi 18-12-2018 \\ Diterima 30-04-2019}

\section{Korespondens}

\section{Nurul Hidayah Base}

nurulhidayahbase@gmail.com

\section{Firzan Nainu}

firzannainu@gmail.com

Fakultas Farmasi, Universitas Hasanuddin, Jalan Perintis

Kemerdekaan Km.10,

Makassar 90245,

Indonesia

Telp. $+62-411-588-556$

Fax +62-411-585-188

Copyright

C 2019 Majalah Farmasi Farmakologi Fakultas

Farmasi · Makassar

Diterbitkan tanggal

30-04-2019

Dapat Diakses Daring

Pada:

http://journal.unhas.ac.id /index.php/mff

\section{ABSTRAK}

Keluwak merupakan hasil fermentasi secara alami dari biji Pangi (Pangium edule Reinw) yang mengandung senyawa yang bersifat sebagai antioksidan. Senyawa antioksidan dapat mempengaruhi kondisi penuaan sel dalam tubuh dengan cara menangkal radikal bebas penyebab stress oksidatif. Penelitian bertujuan untuk mengetahui efek ekstrak keluwak terhadap aktivitas reproduksi Drosophila melanogaster. Dalam penelitian ini digunakan lalat jantan dan lalat betina yang diberi pakan normal (kontrol sehat), ekstrak keluwak 1,25\% dan vitamin C selama 15 hari. Selanjutnya, jumlah total pupa dan jumlah lalat dewasa yang berhasil berkembang dari pupa dihitung setiap tiga hari. Hasil penelitian menunjukkan bahwa ekstrak keluwak 1,25 \% dan vitamin C dapat meningkatkan jumlah pupa dan anak dibandingkan dengan kontrol sehat. Dengan demikian dapat disimpulkan bahwa ekstrak etanol keluwak dapat meningkatkan aktivitas reproduksi Drosophila melanogaster.

\section{PENDAHULUAN}

Indonesia merupakan salah satu negara yang memiliki potensi sumber bahan baku obat yang sangat beragam. Sebagian besar di antaranya sudah dibuktikan secara empiris digunakan oleh masyarakat berdasarkan informasi yang diperoleh secara turun-temurun dalam lingkungan keluarga dan masyarakat sekitarnya (1). Pembuktian melalui penelitian ilmiah dan secara klinik telah diaplikasikan dalam praktek kefarmasian di lapangan. Jenis penyakit yang semakin beragam dan adanya komplikasi berbagai penyakit memerlukan perhatian khusus dalam proses penyembuhannya (2).

Saat ini, terlihat kesan bahwa sebagian besar masyarakat lebih memilih pengobatan secara tradisional dibandingkan dengan pengobatan konvensional karena banyaknya efek samping yang terjadi (2). Selain untuk pengobatan, masyarakat juga mulai memperhatikan penggunaan bahan-bahan alam untuk menjaga kondisi tubuh agar tetap sehat dan prima walaupun pada usia lanjut $(2,3)$. Salah satunya adalah dengan melalui pengunaan antioksidan.

Antioksidan merupakan komponen yang dapat membantu melindungi sel dalam tubuh dari serangan radikal bebas baik yang berupa antioksidan internal maupun antioksidan eksternal. Beberapa senyawa yang bersifat sebagai antioksidan juga berpengaruh terhadap proses penuaan (4).

Keluwak merupakan biji buah pangi (Pangium edule Reinw) yang telah difermentasi selama \pm 40 hari didalam tanah. Keluwak memilki aroma dan cita rasa yang khas sehingga memberikan kenikmatan pada makanan yang diolah dengan menggunakan keluwak. Ekstrak non-minyak keluwak mengandung senyawa antioksidan yang tinggi yang diduga merupakan golongan fenolik terkonjugasi $(5,6)$. Aktivitas antioksidan biji pangi signifikan meningkat setelah difermentasi (keluwak) baik pada fraksi polar maupun nonpolar (7).

Antioksidan dalam tanaman dapat dikonsumsi melalui makanan sehari-hari seperti pada sayur dan buah. Antioksidan dapat menangkal radikal bebas dan dapat menetralisir keadaan sel yang mengalami stress oksidatif dengan cara mengaktivasi atau memodulasi ekpresi gen tertentu yang mampu menetralkan radikal bebas yang terbentuk. Salah satu efek dari antioksidan adalah dapat memperbaiki kondisi penuaan yang disebut dengan anti-aging (8). Salah satu parameter dalam menilai kondisi penuaan (aging) pada mahluk hidup adalah status aktivitas reproduksi.

Salah satu organisme model yang dapat digunakan untuk menilai aktivitas anti-aging adalah lalat buah (Drosophila melanogaster) $(9,10)$. Pada lalat buah, tingkat penuaan dapat dipengaruhi oleh aktivitas seksual dan aktivitas reproduksi. Meningkatnya aktivitas seksual individu jantan dalam menyuplai lalat betina berefek terhadap menurunnya kualitas hidup lalat jantan. Dari beberapa penelitian melaporkan bahwa kemampuan reproduksi lalat betina bersifat konsisten. Kelangsungan hidup lalat betina lebih panjang daripada lalat jantan. Perkawinan dapat mempengaruhi faktor fisiologi dan tingkah laku lalat betina termasuk meningkatnya jumlah produksi telur $(11,12)$.

Kemampuan kawin lalat jantan kira-kira tiga kali lipat lebih lama pada usia 6 minggu karena jumlah sperma tidak menurun hingga usia 40 hari. Penurunan kesuburan terkait usia dapat disebabkan oleh keterbatasan fisik dan perubahan perilaku saat terjadi penuaan (13). 


\section{METODE PENELITIAN}

\section{Rancangan dan Lokasi Penelitian}

Penelitian ini merupakan jenis penelitian eksperimental laboratorium yang dilakukan dari bulan Maret sampai bulan Juni 2017 di Laboratorium Biofarmaka, Pusat Kegiatan Penelitian, Universitas Hasanuddin.

\section{Alat dan Bahan Penelitian}

Alat yang digunakan adalah Rotavapor, Timbangan, Oven (Memmert), Stereo Microskop (Motic), Timbangan analitik (Sartorius), Botol Kultur Lalat Buah, Cawan porselin, Vial Drosophila (Biologix), Pinset (Taiyo electric).

Bahan-bahan yang digunakan antara lain Keluwak, Drosophila melanogaster genotip $w^{1118}$, Etanol $70 \%$, nHeksan, Pakan lalat, air steril.

\section{Pengambilan dan Penyiapan Sampel}

Sampel yang diambil berupa keluwak yang bermutu baik diperoleh dari kabupaten Soppeng. Keluwak diambil dan dibersihkan dari kulitnya, isi dikeluarkan dan dipotongpotong kecil dan dikeringkan di oven pada suhu $50^{\circ} \mathrm{C}$ Keluwak diekstraksi secara maserasi (14). Keluwak ditimbang sebanyak 435 gram lalu diekstraksi dengan pelarut n-heksan selama 1 x 24 jam untuk menghilangkan lemak dan minyak yang terkandung dalam kluwak, pelarut nheksan disaring dan ampas diekstraksi kembali dengan etanol 70\% selama 1 x 24 jam, dilakukan remaserasi sebanyak dua kali. Maserat yang diperoleh diuapkan dengan alat rotavapor pada suhu $60^{\circ} \mathrm{C}$ hingga diperoleh ekstrak kental (15).

\section{Pembuatan Pakan Lalat}

Untuk membuat satu liter pakan lalat, dibutuhkan komposisi pakan antara lain corn meal 75 g, glukosa 45 g, yeast $25 \mathrm{~g}$, agar $9 \mathrm{~g}$, metil paraben $15 \% 43 \mathrm{ml}$, asam propionate $38 \mathrm{ml}$ dan air steril hingga 1 liter. Semua bahan dicampurkan dan dimasak hingga kental dan dipindahkan kedalam wadah vial (16). Untuk membuat pakan yang mengandung ekstrak 1,25\%, ekstrak dipipet masing-masing sebanyak $25 \mu \mathrm{l}$, dari stok larutan ekstrak dan air (1:1) dan dicampurkan dengan $2 \mathrm{ml}$ pakan dalam vial biologix. Setelah memadat dibiarkan pada suhu ruangan 1 sampai 2 hari dan siap untuk digunakan.

Untuk pakan yang mengandung vitamin $\mathrm{C}$ dibuat larutan stok vitamin $C$ dalam $10 \mathrm{ml}$ air dengan menimbang vitamin $C$ sebanyak $70 \mathrm{mg}$ dan dilarutkan dengan air bebas $\mathrm{CO}_{2}$ dalam labu tentukur $10 \mathrm{ml}$, setelah larut sempurna dicukupkan volumenya hingga tanda. Untuk membuat pakan yang mengandung $20 \mathrm{mM}$ vitamin $\mathrm{C}$ dipipet sebanyak $125 \mu \mathrm{l}$ larutan stok dan dicampurkan ke dalam dua ml pakan (17).

\section{Uji Aktivitas Reproduksi}

Disiapkan lalat yang berumur 0-1 hari dan dipilih lalat jantan dan betina masing-masing sebanyak 2 ekor untuk tiap vial dan diberi pakan kontrol sehat, ekstrak keluwak 1,25\% dan vitamin $\mathrm{C}$ sebagai kontrol positif. Lalat dibiarkan mating selama 3 hari lalu dipindahkan pada vial yang berisi pakan baru dengan perlakuan yang sama setiap 3 hari selama 15 hari. Setiap tiga hari dihitung jumlah pupa dan anak pada masing - masing grup perlakuan $(18,19)$.

\section{HASIL DAN PEMBAHASAN}

\section{Hasil Ekstraksi}

Ekstraksi sampel menggunakan pelarut etanol 70\% dengan metode ekstraksi secara maserasi diperoleh rendemen sebesar 12,67\% dari ekstrak sebesar 55,13 g dan simplisia seberat 435 g. Rendemen ekstrak diperoleh dari perbandingan antara berat ekstrak yang dihasilkan dan berat simplisia yang ditimbang awal.

\section{Aktivitas Reproduksi}

Ekstraksi sampel menggunakan pelarut etanol 70\% dengan Hasil aktivitas reproduksi selama 15 hari dengan kelompok perlakuan berbeda dapat dilihat perbandingan jumlah pupa dan anak pada gambar berikut:

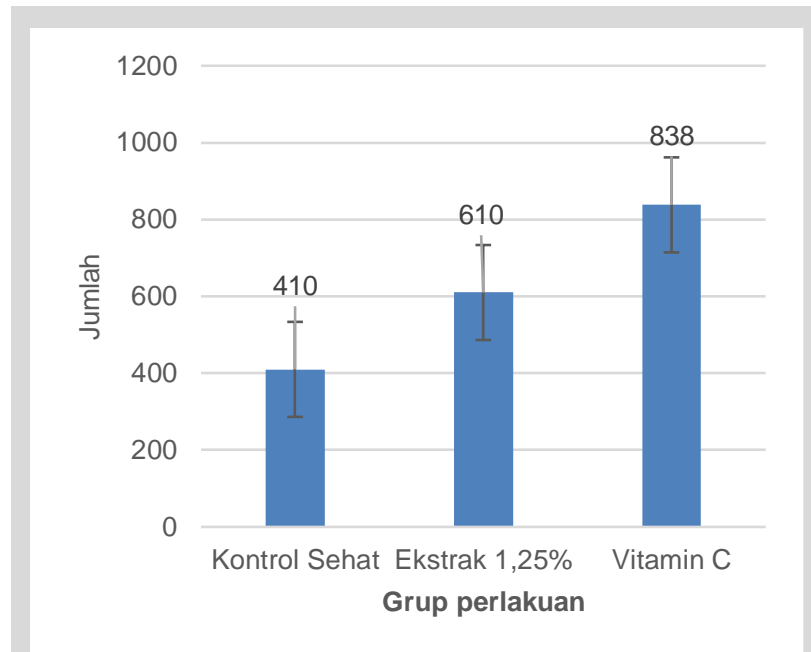

Gambar 1. Jumlah pupa hasil uji aktivitas reproduksi Drosophila melanogaster $w^{1118}$ selama 15 hari.

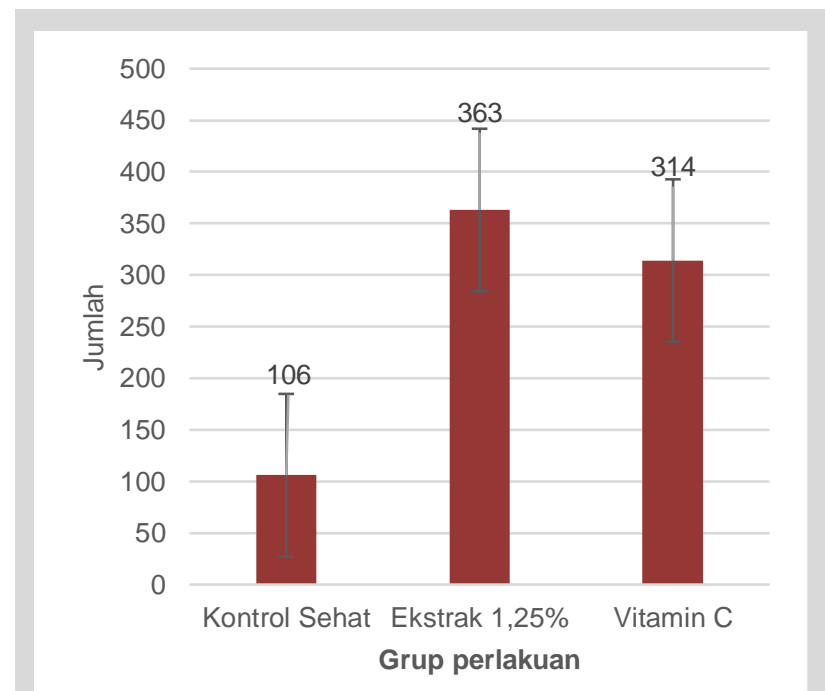

Gambar 2. Jumlah anak hasil uji aktivitas reproduksi Drosophila melanogaster $w^{1118}$ selama 15 hari.

Penuaan merupakan suatu proses yang terjadi secara alami pada kondisi tubuh manusia. Kondisi penuaan dapat dipengaruhi oleh beberapa faktor seperti lingkungan, stress, sakit maupun karena pola hidup yang tidak sehat. Salah satu parameter yang dapat mempengaruhi kualitas hidup dan kondisi penuaan adalah kemampuan dalam aktivitas reproduksi mahluk hidup.

Pengujian aktivitas reproduksi dilakukan menggunakan model hewan uji Drosophila melanogaster dengan menggunakan ekstrak keluwak 1,25\% yang dibandingkan dengan kontrol sehat dan vitamin $\mathrm{C}$ sebagai kontrol positif. Hasil penelitan yang telah dilakukan menunjukkan bahwa aktivitas reproduksi menggunakan ekstrak keluwak dapat meningkatkan jumlah pupa dan anak jika dibandingkan dengan kontrol sehat. Vitamin $\mathrm{C}$ sebagai kontrol positif menghasilkan jumlah pupa terbanyak yaitu 838 pupa 
dibandingkan ekstrak keluwak, namun jumlah anak paling banyak dihasilkan oleh ekstrak keluwak yaitu 363 anak sedangkan vitamin C memiliki 314 anak.

Lalat betina dapat berpasangan dengan banyak lalat jantan sehingga dapat menghasilkan keturunan dari banyak pasangan. Jantan dapat mempengaruhi aspek perilaku mating melalui fenomena kompetisi sperma. Pertahanan sperma merupakan kemampuan seekor jantan untuk mengurangi kemungkinan seekor betina memilih pasangan dan menghasilkan keturunan lalat jantan lainnya. Sistem reproduksi pada lalat betina dapat berubah seiring bertambahnya usia. Penyebaran telur pada populasi lalat betina mencapai maksimal 4 hari dan menurun dengan mantap setelahnya dan menjadi minimal setelah 50 hari. Penempelan telur pada betina diuji secara individual juga menurun seiring bertambahnya usia (13). Pada masa awal mating terjadi induksi peletakan telur yang tinggi pada lalat betina yang berefek reversible terhadap mortalitas dan pada tahap akhir kehidupan, betina secara tajam menunjukkan pengurangan peletakan telur, namun belum dapat dipastikan adanya hubungan antara reproduksi dan lifespan (11).

Perlakuan selama 15 hari menunjukkan bahwa ekstrak keluwak 1,25\% menghasilkan jumlah anakan yang lebih banyak daripada vitamin $\mathrm{C}$ meskipun jumlah pupa lebih banyak pada pemberian vitamin C. Hal ini menunjukkan bahwa ekstrak keluwak memiliki kemampuan untuk mempertahankan kondisi pupa sehingga dapat berubah menjadi anak. Adanya satu atau lebih kandungan kimia yang terkandung dalam ekstrak keluwak kemungkinan dapat mempengaruhi kualitas pupa sehingga dapat bertahan menjadi anak dibandingkan dengan kontrol sehat dan vitamin C, Hasil ini menunjukkan bahwa Ekstrak keluwak memiliki kemampuan untuk meningkatkan hasil resproduksi daripada kontrol sehat, namun perlu dilakukan penelitian lebih lanjut untuk memastikan hal tesebut.

\section{KESIMPULAN}

Berdasarkan hasil penelitian yang telah dilakukan, maka dapat disimpulkan bahwa ekstrak keluwak dengan konsentrasi 1,25 \% dapat meningkatkan aktivitas reproduksi D. melanogaster.

\section{UCAPAN TERIMA KASIH}

Penelitian ini dilakukan atas bantuan dana pendidikan BPPDN dari Dikti tahun 2015 (kepada NHB) dan hibah penelitian BMIS dan WCU-PPI (kepada FN). Terimakasih kepada Prof
Yoshinobu Nakanishi (Kanazawa University, Jepang) atas pemberian lalat buah sebagai model uji in vivo. Terimakasih kepada Tim UFRG (Unhas Fly Research Group) atas kerjasama yang baik selama penelitian.

\section{DAFTAR PUSTAKA}

1. Susiarti S, (2015). Pengetahuan dan pemanfaatan tumbuhan obat masyarakat lokal di Pulau Seram, Maluku bidang botani, Pusat Penelitian Biologi, Lembaga Ilmu Pengetahuan Indonesia .Bogor.

2. Orhan I E, (2014), Pharmacognosy: Science of natural products in drug discovery, Bioimpacts, 4(3):109-110.

3. Rashrash M, Schommer J C, Brown L M, (2017), Prevalence and predictors of herbal medicine use among adults in the United States, Journal of Patient Experience, 4(3):108-113.

4. Young I S, Woodside J V, (2001), Antioxidants in health and disease, Journal of Clinical Pathology, 54:176-186

5. Andarwulan N, Fardiaz S, Apriyantono A, Hariyadi P, Shetty, K, (1999), Mobilization of primary metabolites and phenolics during natural fermentation in seeds of Pangium edule Reinw, Process Biochemistry, 35, 197-204.

6. Anwar E, (1992), Isolasi antioksidan dari biji picung (Pangium edule Reinw) terfermentasi, IPB. Bogor.

7. Santoso M, Yamaguchi T, Matoba T, Takamura H, (2014), Effects of pit fermentation and thermal cooking process on the antioxidant activity and components of Pangium edule seeds, 4(4):202-213.

8. Dua D, Srivastava N S, (2016), A study on antioxidant and anti-aging properties of few medicinal plants, International Journal of Pharmacy and Pharmaceutical Sciences. 8(1):344-347.

9. Omelyanchuk L V, Shaposhnikov M V, Moskalev, A A, (2015), Drosophila nervous system as a target of aging and anti-aging interventions, Frontiers in Genetics. 6(89):1-5.

10. Jafari, M, (2010), Drosophilla melanogaster as a model system for the evaluation of anti-aging compounds, Fly, 4(3):253-257.

11. Illiadi K G, Boullianne G L, (2010), Age related behavioral changes in Drosophila, Ann N. Y. Acad. Sci. 1197:9-18.

12. Austad S N, Fischer K E, (2016), Sex differences in lifespan, Cell metabolism, 23(6): 1022-1033.

13. Grotowiel M S, Martin I, Bhandari P, Cook-Wiens E, (2005), Funtional senescence in Drosophila melanogaster, Aging Research Reviews, $4(3): 372-397$.

14. Mangunwardoto W, Ismaini L, Heruwati E S, (2008), Analisis senyawa bio aktif dari ekstrak biji Picung (Pangium edule Reinw) segar, Berita Biologi, $9(3): 259-264$

15. Departemen Kesehatan Repulik Indonesia, (2008), Farmakope Herbal Indonesia Edisi I. Direktorat Jenderal Bina Kefarmasian dan Alat Kesehatan.

16. Sun, Y, Yolitz J, Wang C, Spangler E, Zhan M, Zhou S, (2013), Aging studies in Drosophila melanogaster. Methods Mol Biol, 1048: 77-93.

17. Bahadoroni S, Bahadoroni P, Philips J P, Hiliker A J, (2008), The effect of vitamin suplementation on Drosophila life span under normoxia and under oxidative stress, The Journals of Gerontology Series A, 63(1): 35-42.

18. Chattopaddhyay D, Chitnis A, Talekar A, Mulay P, Makkar M, James I, Thirummugaa K, (2017), Hormetic efficacy of rutin to promote longevity in Drosophila melanogaster. Biogerontology, 18(3):397-411

19. Panchal K, Tiwari A K, (2017), Drosophila melanogaster "a potential model organism" for identification of pharmacological properties of plants/ plant-derived components. Biomedicine \& Pharmacotherapy, 89:13311345 